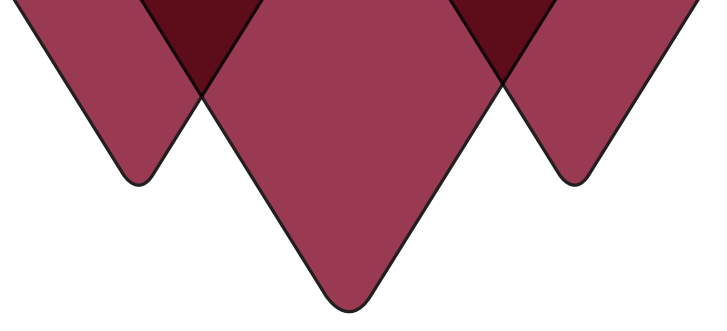

\title{
About the Artist / À propos de l'artiste
}

$\grave{\mathbf{E}}$

vE K. Tremblay, a photographer and multidisciplinary artist born in 1972, grew up in Val-David, spending time in her father Alain-Marie Tremblay's ceramics workshop and that of her stepmother, the artist Indira Nair. Inspired by the bipolar illness of her mother who fell ill shortly after her birth, the exploration of consciousness, transformation, and reconstruction are at the heart of her work, from fragmented and unreal scenarios to mindscapes and meditative images. Her works from 1997 and 2006 are inspired by scientific readings, her studies in the fields of French literature, theatre, and photography, as well as her experiences as a set photographer in the TV and film business. In-situ scenes, performances, and rituals played with loved ones and scientists explore inner worlds, defined within the frame and the photographic surface. Begun in Berlin where she lived for three years, the cycle EKTBF45I / EKTFF45I (2007-2015) explores the mechanisms of memorization and oblivion around Ray Bradbury's dystopian book Fahrenheit 45I (1953), depicting a society of consumption and anti-intellectualism. Her works are presented as experimental narrations in a variety of different mediums. Since 20I3, she has also been exploring the fusion of ceramics and photography. She lives and works in both Montreal and the New York area. Named to the long list of the Sobeys Art Award in 2012, her works have been exhibited and published internationally. Among many other institutions, her works have been exhibited at the National Museum of Fine Arts of Québec, MACVAL, Bergen Kunsthall, Kunstraum Kreuzberg, Museum of Contemporary Art of Montreal, Momentum 7, the Nordic Biennale, Le Musée d'art contemporain des Laurentides, and The Petach Tikva Museum of Art.

$\grave{\mathbf{E}}$

E K. Tremblay, photographe et artiste pluridisciplinaire née en I972, a grandi à Val-David, fréquentant l'atelier de céramique de son père Alain-Marie Tremblay et celui de sa belle-mère, l'artiste Indira Nair. Inspirée par la maladie bipolaire de sa mère tombée malade peu de temps après sa naissance, l'exploration de la conscience, de la transformation et de la reconstruction sont au cœur de son travail où l'on passe 
